\title{
Utilization of Geo-spatial Technologies for Solid Waste Management: A Case Study-Islamabad, Pakistan
}

\author{
Muhammad Khubaib Abuzar ${ }^{(1)}$ Naheed Fatima $^{(1)}$ Dr Sher Jamal Khan ${ }^{(2)}$ Dr Syed Amir Mahmood ${ }^{(3)}$ \\ and Fiza Sarwar ${ }^{(1)}$ \\ ${ }^{1,}$ Earth \& Environmental Science Department, Bahria University, Islamabad, Pakistan. \\ ${ }^{2}$ Institute of Environmental Sciences and Engineering, School of Civil and Environmental Engineering, National \\ University of Sciences\& Technology (NUST), Islamabad, Pakistan. \\ ${ }^{3}$ Chairman Department of Space Science, University of the Punjab, Lahore, Pakistan.
}

\begin{abstract}
Municipal solid waste management is very significant environmental issue now days especially in the developing countries. Municipal solid waste management is considered as one of the most serious environmental issues being faced by municipal authorities in developing countries due to increase in waste generation and its ineffective collection plan. There is a considerable amount of solid waste which is directly disposed off without going through segregation process. The improper management of solid waste leads to transmission of different diseases via air and water pollution. This study was aimed to analyze the present situation of solid waste management in four sectors of capital city Islamabad (F-6, F-7, G-6 and G-7). The objective of the study was to estimate the amount of solid waste generated from these four sectors and geographical location of the existing bins, skips and trolleys. Existing waste management plan is inadequate against the increased waste generation and low collection capacity from the municipal authorities. This study reveals that GIS tool can be useful to assist municipal authorities to improve the present solid waste management system within urban areas of the developing countries like Pakistan.
\end{abstract}

Keywords: Municipal Solid Waste (MSW), Geographic Information System (GIS), Municipal Bin locations, Global Positioning System (GPS)

\section{Introduction}

Improper municipal solid waste management (MSWM) is considered to be a threat to the environment and poses to be a significant problem in developing countries like Pakistan. Rapid population growth, urbanization and industrialization in the cities of developing countries have made MSWM a monumental issue (Narayana, 2008). The purpose of solid waste management is to provide uncontaminated environment for people without disturbing natural resources (McDougall et al., 2001). MSWM system has improved with the help of new technologies like GIS. Characteristics and composition of solid waste varies regarding the topography of the area, different seasons, food habits, commercial status of the city,etc (Meshram et al., 2009).

Due to rapid growth in population in the developing countries, it is becoming a challenge for municipal authorities to handle solid waste from the collection point to disposal in a sustainable way (Amponsah et al., 2004). Solid waste in developing countries comprise mainly of organic material and particularly, in India, there is an increased fraction of biodegradable material and use of plastic and paper increases progressively (Chattopadhyay et al., 2008). Solid waste management practices vary for developed and developing countries. In developed countries, landfills are now bracketed as obsolete after noticing several problems like pollution and contamination of groundwater by leachate and remaining soil contamination after landfill closure and simple nuisance problems (G.E.Blight et al., 1996).

Solid waste management (SWM) is one of the major problems for environmental degradation in Pakistan. Improper management of solid waste causes hazards to dwellers. The average rate of waste generation from all type of municipal controlled areas varies from $1.896 \mathrm{~kg} /$ house/day to $4.29 \mathrm{~kg} / \mathrm{house} /$ day in a few major cities (Pak EPA, 2005). Currently, a management plan does not exist to carry out proper municipal waste collection, transportation and disposal regardless of the size of the city. Waste amount survey in Islamabad for the first time 
in Pakistan was conducted in 2004. About $60 \%$ of the total waste generated is being collected by municipal authorities and the remaining waste scattered on streets, road corners and plots (Pak-EPA, 2005).

\section{Objectives of study}

This study aims to analyze the existing waste management situation, estimation of the waste generation and relocation of the bins by using GIS in the four sectors of Islamabad for better solid waste management.

\section{Methodology}

Methodology followed in this study included primary and secondary data collection along with the use of Google maps to identify the location of the bins and their relocation. The complete methodology adopted for this research is shown in figure 1 .

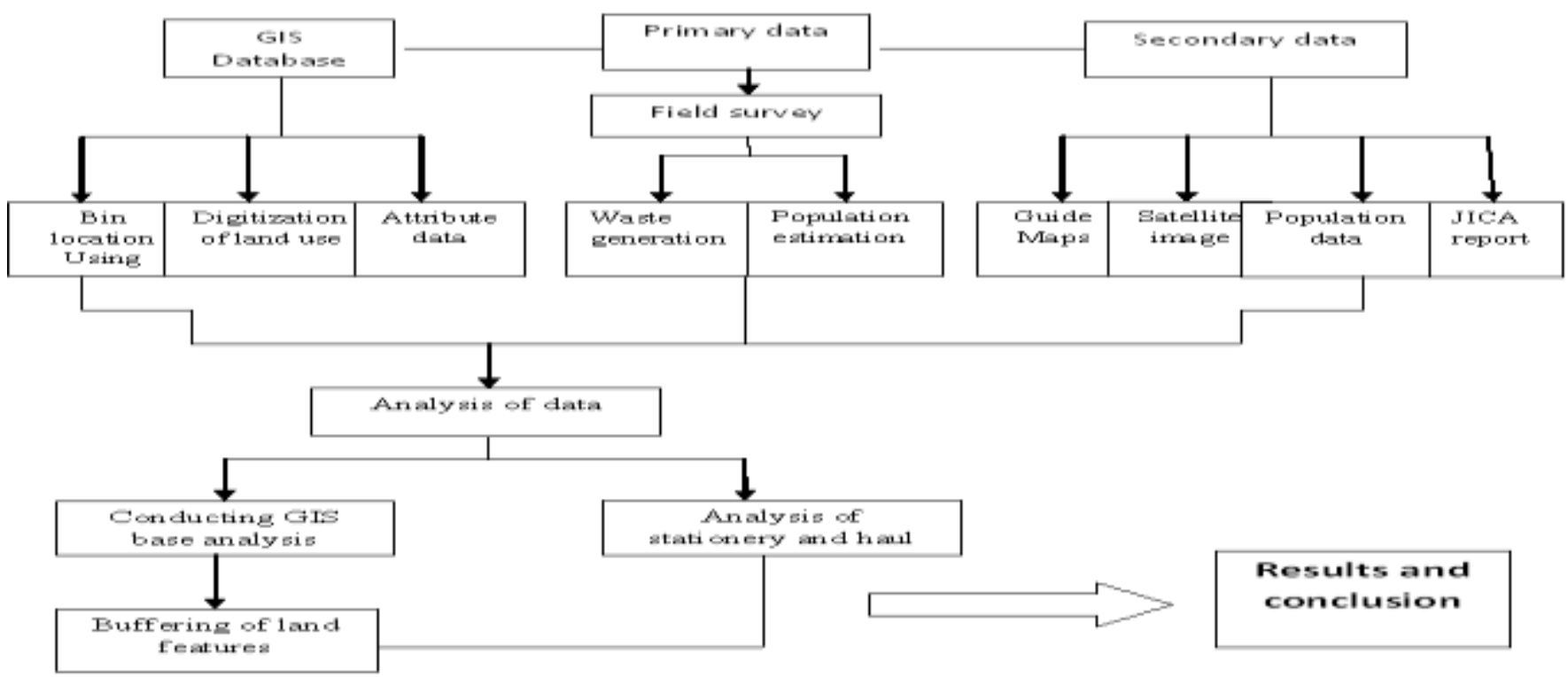

Fig. 1: Conceptual Diagram of Methodology

\section{Results}

\subsection{Population estimation}

Projected population was calculated on the basis of the census data 1998 for the study area. Projected population in sector $G$ is higher than sector F. G-7/2 is most populated sub-sector and F-7/3 is the least populated sector. The projected population against population according to 1998 census is plotted in the figure 2 . 


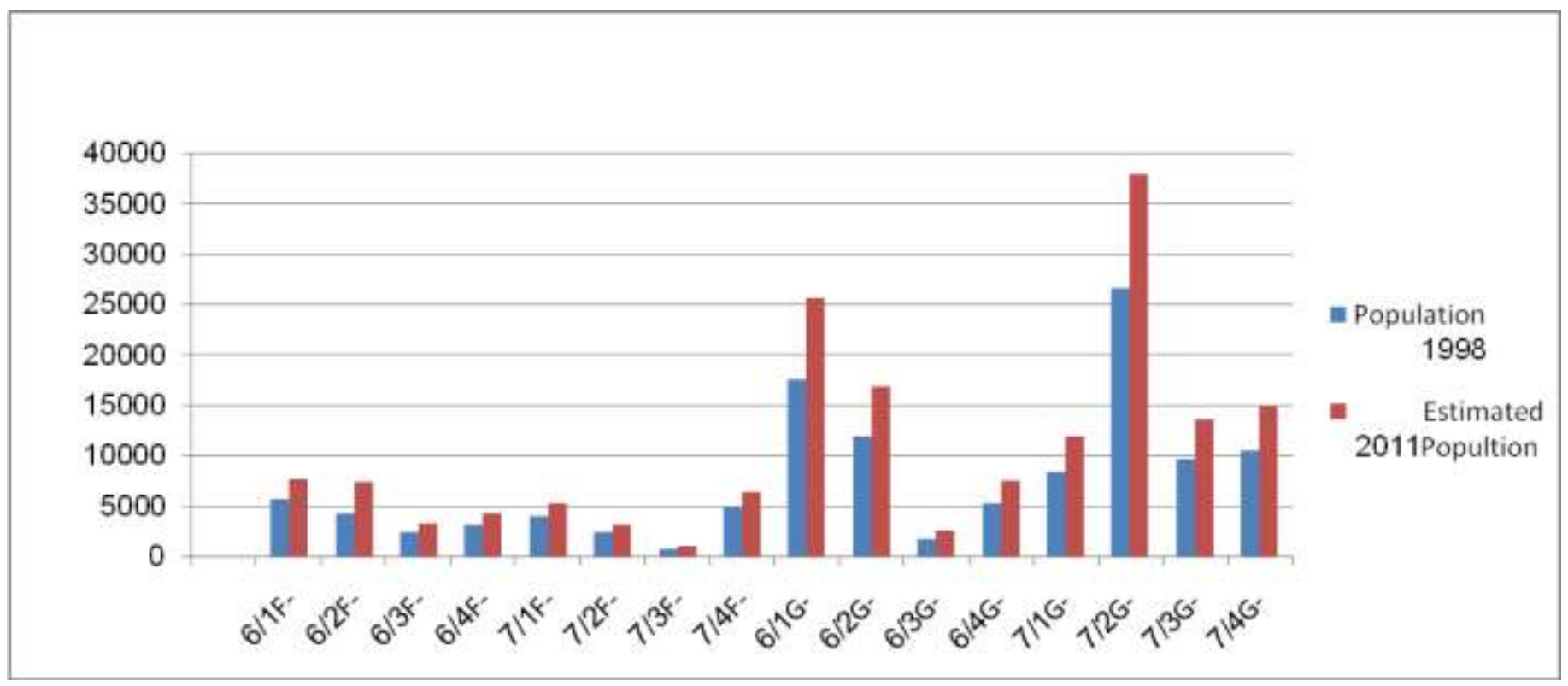

Fig. 2: Population 1998 versus projected 2011

\subsection{Waste Generation}

Waste generation was calculated on the basis of population of the each sector that was at the rate of per capita 0.61(units) (JICA and World Bank). Figure 3 shows that the carrying capacity of waste bins is much less than the waste generated by the study area. More number of waste bins is required for the waste collection. * 1 cubic yard $=0.764$ cubic meter (convert yd to cubic meter) (include \% increase or decrease of waste capacity). The total waste generation against the total capacity of the skips/trolleys with their difference to capacity is shown in table 1.

TABLE I : Comparison of waste generation with bins capacity

\begin{tabular}{|l|l|l|l|l|l|l|}
\hline Sectors & Population & $\begin{array}{l}\text { Total waste } \\
\text { generation } \\
\text { (yd3/d) }\end{array}$ & $\begin{array}{l}\text { No. of } \\
\text { Trolley }\end{array}$ & $\begin{array}{l}\text { No. of } \\
\text { Skips }\end{array}$ & $\begin{array}{l}\text { Total capacity of } \\
\text { Skip/Trolley (yd3) }\end{array}$ & $\begin{array}{l}\text { Difference between waste } \\
\text { generation and carrying } \\
\text { capacity }\end{array}$ \\
\hline F-6/1 & 7,632 & 34.69 & 22 & 3 & 40.25 & +16.02 \\
\hline F-6/2 & 7421 & 33.773 & 10 & 4 & 32.40 & -3.9 \\
\hline F-6/3 & 3279 & 14.90 & 11 & 3 & 28.15 & 13.35 \\
\hline F-6/4 & 4250 & 19.21 & 33 & 1 & 42.18 & +22.97 \\
\hline F-7/1 & 5277 & 24 & 15 & 1 & 21.85 & -2.15 \\
\hline F-7/2 & 3182. & 14.46 & 22 & 2 & 34.90 & +20.44 \\
\hline F-7/3 & 1013 & 4.60 & 10 & 2 & 14.21 & +9.61 \\
\hline F-7/4 & 6420 & 29.18 & 15 & 2 & 27.20 & -1.98 \\
\hline G-6/1 & 17,959 & 116.4 & 33 & 0 & 35.82 & -81.19 \\
\hline G-6/2 & 11,845 & 76.77 & 32 & 0 & 38.21 & -38.56 \\
\hline G-6/3 & 1745 & 11.30 & 14 & 0 & 15.39 & +4.09 \\
\hline G-6/4 & 5249 & 34 & 19 & 0 & 20.90 & +13.1 \\
\hline G-7/1 & 11860 & 53.90 & 0 & 9 & 48.16 & -5.74 \\
\hline G-7/2 & 38075 & 173 & 1 & 4 & 22.5 & -150.5 \\
\hline G-7/3 & 9575 & 62 & 3 & 6 & 37.63 & -24.37 \\
\hline G-7/4 & 10,432 & 67.61 & 19 & 1 & 26.25 & +41.36 \\
\hline
\end{tabular}




\subsection{Analysis of Stationery container system}

Stationary container system is used for the collection of all type of waste. Stationary container systems are of two types. One is manually loaded collection vehicle and other is mechanically loaded vehicle. Here the analysis of mechanically loaded vehicles is taken in to consideration shown in table2.

TABLE II: Analysis of stationery container system

\begin{tabular}{|l|l|l|l|l|l|l|l|l|}
\hline Sector & $\begin{array}{l}\text { Collection } \\
\text { frequency } \\
\text { (times/wk) }\end{array}$ & $\begin{array}{l}\text { No. of } \\
\text { pick up } \\
\text { location }\end{array}$ & $\begin{array}{l}\text { Total no. } \\
\text { of } \\
\text { container }\end{array}$ & $\begin{array}{l}\text { Total } \\
\text { waste, } \\
\text { yd3/d }\end{array}$ & $\begin{array}{l}\text { Pick up } \\
\text { time } \\
\text { (h/trip) }\end{array}$ & $\begin{array}{l}\text { No. of } \\
\text { trips, (trips } \\
\text { per day) }\end{array}$ & $\begin{array}{l}\text { Total } \\
\text { time } \\
\text { (h/trip) }\end{array}$ & $\begin{array}{l}\text { Time } \\
\text { required } \\
\text { (h/day) }\end{array}$ \\
\hline F-6/1 & 7 & 9 & 22 & 45.38 & 2.24 & 1.4 & 2.53 & 4.48 \\
\hline F-6/2 & 7 & 4 & 10 & 44.12 & 1.8 & 1.4 & 2.08 & 3.61 \\
\hline F-6/3 & 7 & 5 & 11 & 19.49 & 1.9 & 0.62 & 2.20 & 1.86 \\
\hline F-6/4 & 7 & 11 & 17 & 25.13 & 2.2 & 0.8 & 2.51 & 2.59 \\
\hline F-7/1 & 7 & 11 & 15 & 31.38 & 2.23 & 0.99 & 2.50 & 3.05 \\
\hline F-7/2 & 7 & 10 & 22 & 18.92 & 2.19 & 0.6 & 2.45 & 1.89 \\
\hline F-7/3 & 7 & 6 & 10 & 6.02 & 1.98 & 0.19 & 2.26 & 0.76 \\
\hline F-7/4 & 7 & 11 & 15 & 38.17 & 2.23 & 1.21 & 2.52 & 3.8 \\
\hline G-6/1 & 7 & 8 & 33 & 152.25 & 2.04 & 4.84 & 2.30 & 12.35 \\
\hline G-6/2 & 7 & 5 & 32 & 100.42 & 1.89 & 3.19 & 2.14 & 8.14 \\
\hline G-6/3 & 7 & 6 & 14 & 14.79 & 2.29 & 0.47 & 2.56 & 1.60 \\
\hline G-6/4 & 7 & 11 & 19 & 44.5 & 2.21 & 1.41 & 2.49 & 4.27 \\
\hline G-7/2 & 7 & 1 & 1 & 226.4 & 1.72 & 7.21 & 1.97 & 16.80 \\
\hline G-7/3 & 7 & 1 & 3 & 81.17 & 1.7 & 2.58 & 1.95 & 5.98 \\
\hline G-7/4 & 7 & 7 & 19 & 88.44 & 1.98 & 2.81 & 2.20 & 7.32 \\
\hline
\end{tabular}

\subsection{Analysis of Haul container system}

Hauled container system is usually used for the collection of solid waste from the sources where the waste generation rate is high shown in table 3.

TABLE III: Analysis of haul container system

\begin{tabular}{|l|l|l|l|l|l|l|l|l|}
\hline Sector & $\begin{array}{l}\text { collection } \\
\text { frequency } \\
\text { times/wk }\end{array}$ & $\begin{array}{l}\text { no. of } \\
\text { pick up } \\
\text { locations }\end{array}$ & $\begin{array}{l}\text { Total no. } \\
\text { of container }\end{array}$ & $\begin{array}{l}\text { waste } \\
\text { generation } \\
\text { yd3/d }\end{array}$ & $\begin{array}{l}\text { pick up } \\
\text { time (h/trip) }\end{array}$ & $\begin{array}{l}\text { no. } \\
\text { of trip/day }\end{array}$ & $\begin{array}{l}\text { Total time } \\
\text { (h/trip) }\end{array}$ & $\begin{array}{l}\text { Time required } \\
\text { Per day }\end{array}$ \\
\hline F-6/1 & 1 & 3 & 3 & 45.38 & 0.83 & 9.65 & 1.05 & 12.08 \\
\hline F-6/2 & 1 & 4 & 4 & 44.12 & 0.84 & 9.38 & 1.07 & 12 \\
\hline F-6/3 & 1 & 1 & 3 & 19.49 & 0.86 & 4.13 & 1.11 & 5.65 \\
\hline F-6/4 & 1 & 1 & 1 & 25.13 & 0.87 & 5.34 & 1.13 & 7.33 \\
\hline F-7/1 & 1 & 1 & 1 & 31.38 & 0.83 & 6.67 & 1.05 & 8.38 \\
\hline F-7/2 & 1 & 2 & 2 & 18.92 & 0.82 & 4.02 & 1.03 & 5.83 \\
\hline F-7/3 & 1 & 2 & 2 & 6.02 & 0.84 & 1.28 & 1.07 & 1.87 \\
\hline F-7/4 & 1 & 2 & 2 & 38.17 & 0.85 & 8.12 & 1.09 & 10.62 \\
\hline G-7/1 & 1 & 8 & 9 & 70.51 & 0.81 & 15 & 1 & 17.66 \\
\hline G-7/2 & 1 & 4 & 4 & 226.4 & 0.79 & 48.17 & 0.86 & 58.46 \\
\hline G-7/3 & 1 & 6 & 6 & 81.17 & 0.81 & 17.27 & 1.01 & 17.5 \\
\hline G-7/4 & 1 & 1 & 1 & 88.44 & 0.78 & 18.81 & 0.95 & 21 \\
\hline
\end{tabular}

\section{GIS Model implementation}

\subsection{Analysis on Waste bins within close proximity of sensitive buildings}

To find the inconvenience to schools, hospitals and religious buildings due to close proximity of the waste bins, a buffer of 20 meters applied around these features in the study area. 40 meter buffer was applied around the hospital and religious places two bands of 20 meter interval each shown in Figure 3. 


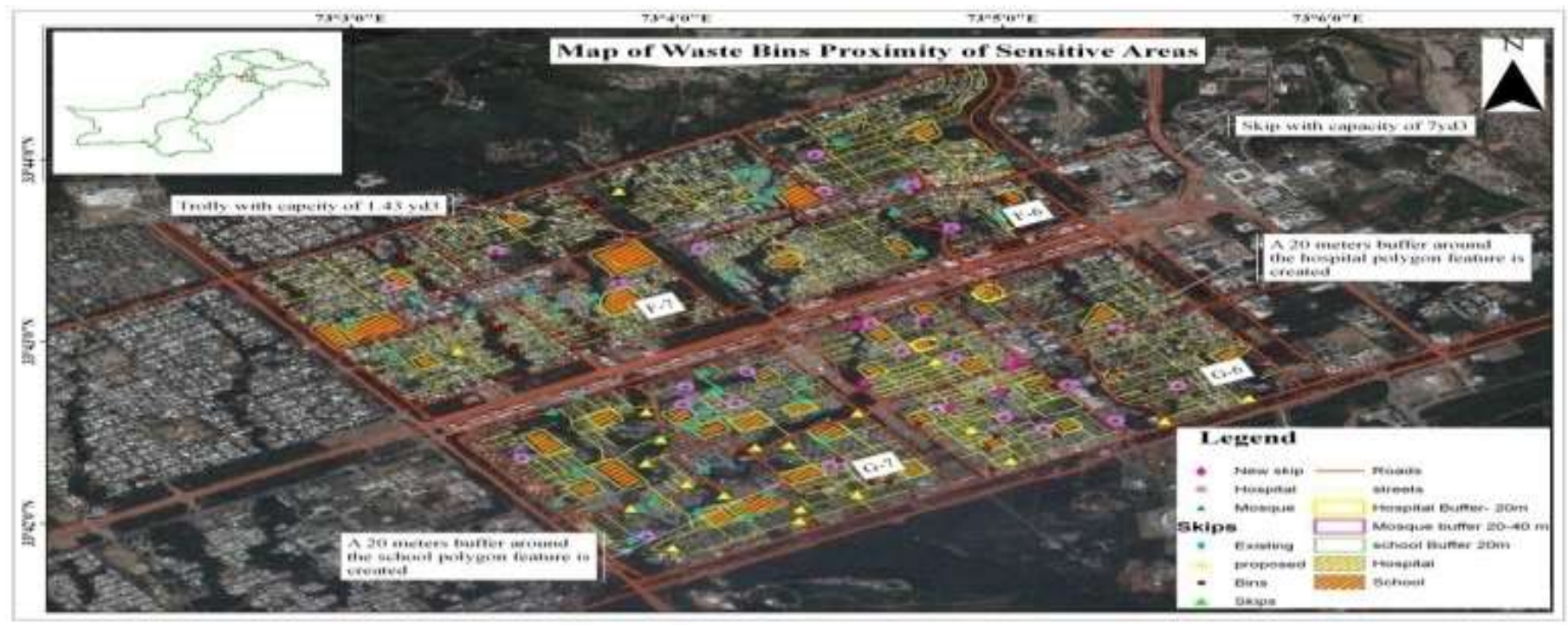

Fig 3: Waste bins within proximity of sensitive area

\subsection{Convenience Distance to all Users}

To check the waste bins proximity from the users to provide the bins at a convenient distance a buffer of 100 meters is created around all the waste bins /trolley shown in Figure 4.

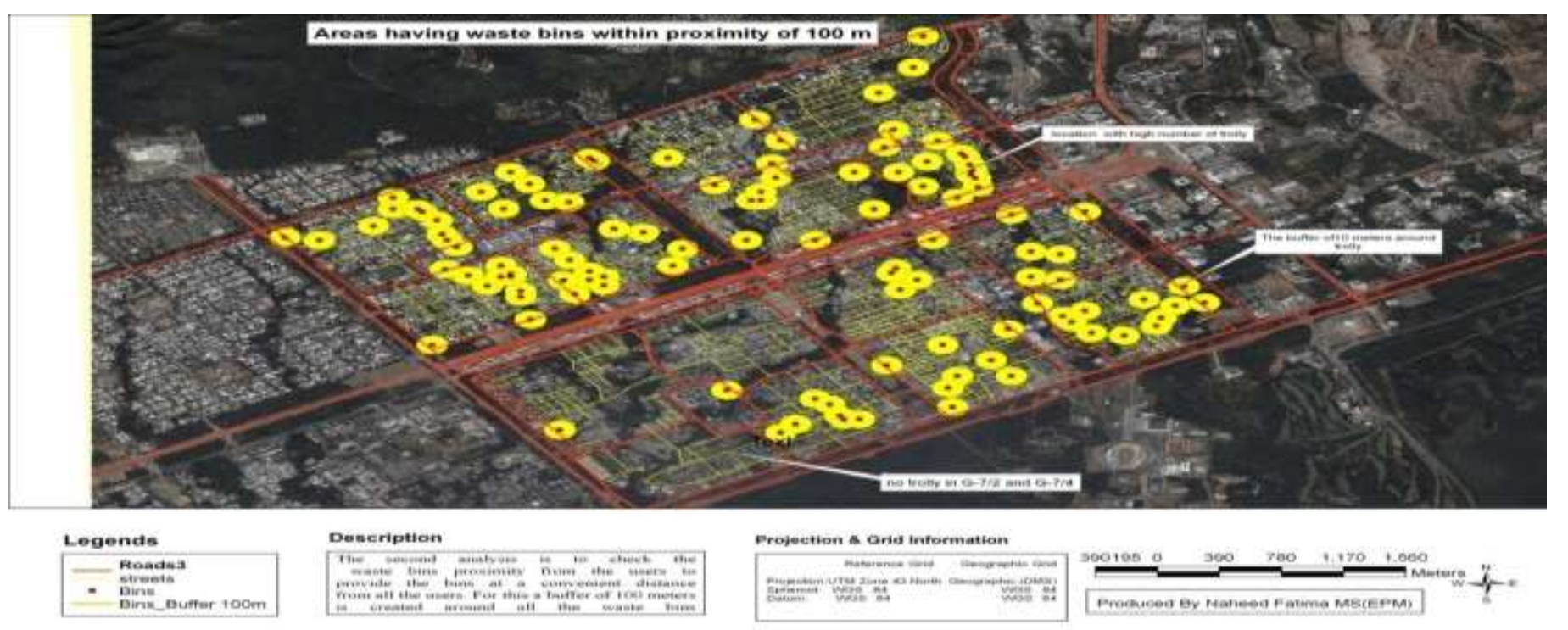

Fig. 4: Areas which do not have waste bin (trolley) within a distance of 100 meters

Similarly a buffer of 300 meters is created around all the waste bins (skips). 

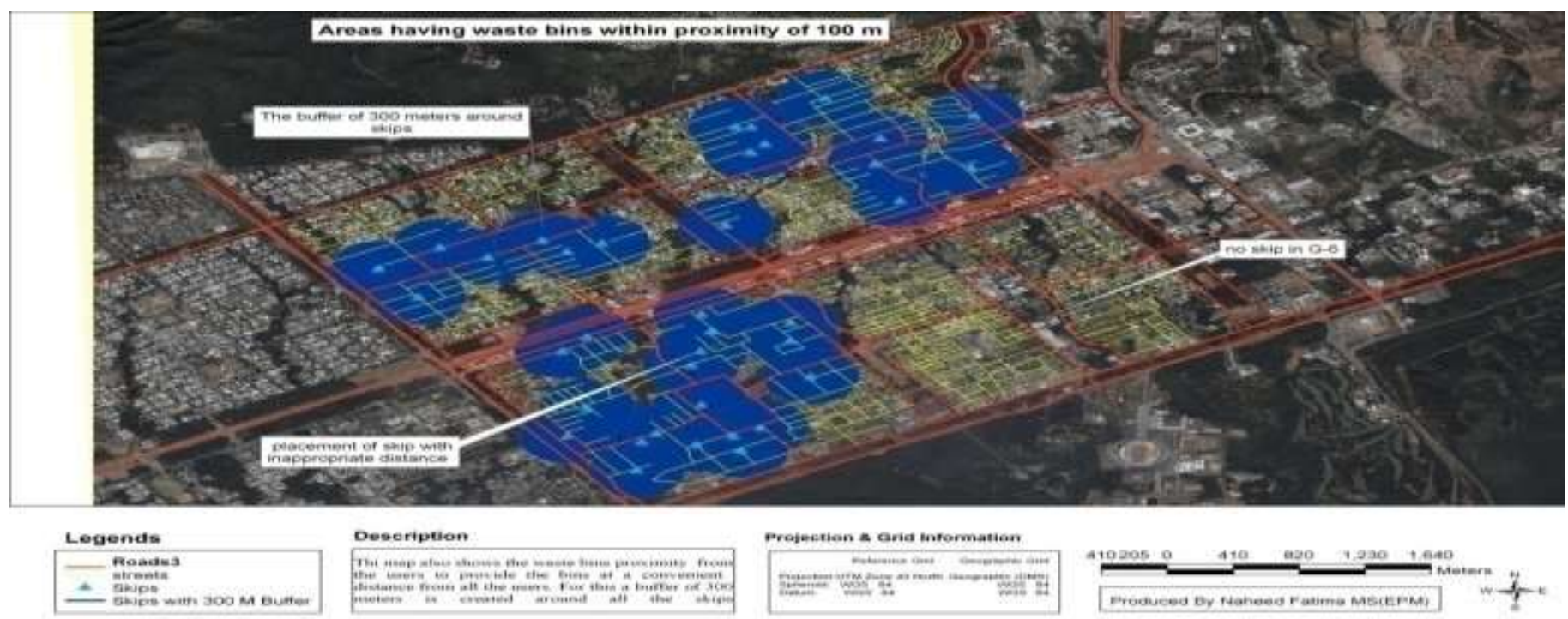

Fig. 5: Areas which do not have waste bin (skip) within a distance of 300 meters

\subsection{Proximity of waste bins from recreational areas}

For checking the proximity of waste bins from recreational areas a buffer of 20 meters was created around parks and playgrounds to identify the bins which come in proximity of 20 meters around the recreational sites.

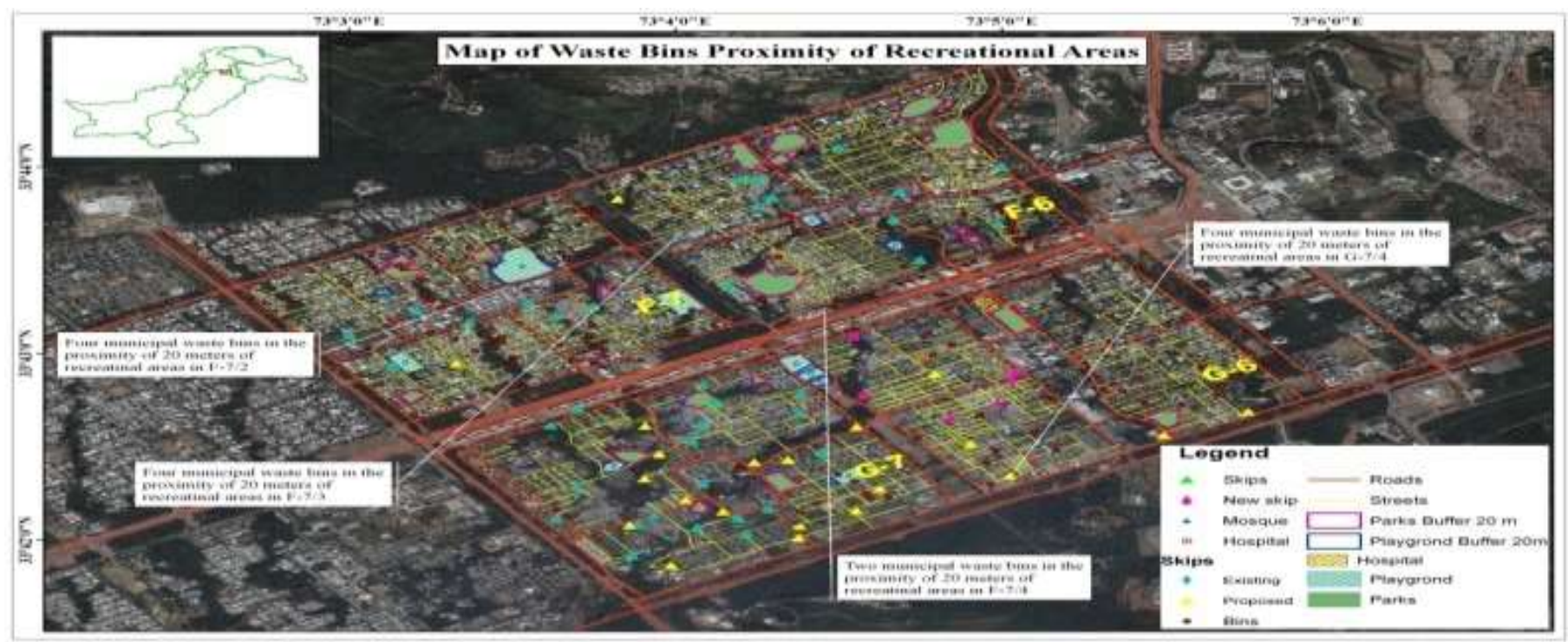

Fig. 6: Waste bins within close proximity of Recreational areas

\subsection{Re-allocation of existing bins}

The reallocation of the waste bin was carried out by finding a suitable location in the areas which needs waste bins. Waste bins (skips) in the case study area which are in close proximity of land use area are required to be moved out of the buffer range of the respective land use area to serve the uncovered areas. Overall, there are 46 proposed trolleys in F-6 sector required to be place in the suitable location considering the buffer range of land use area. 


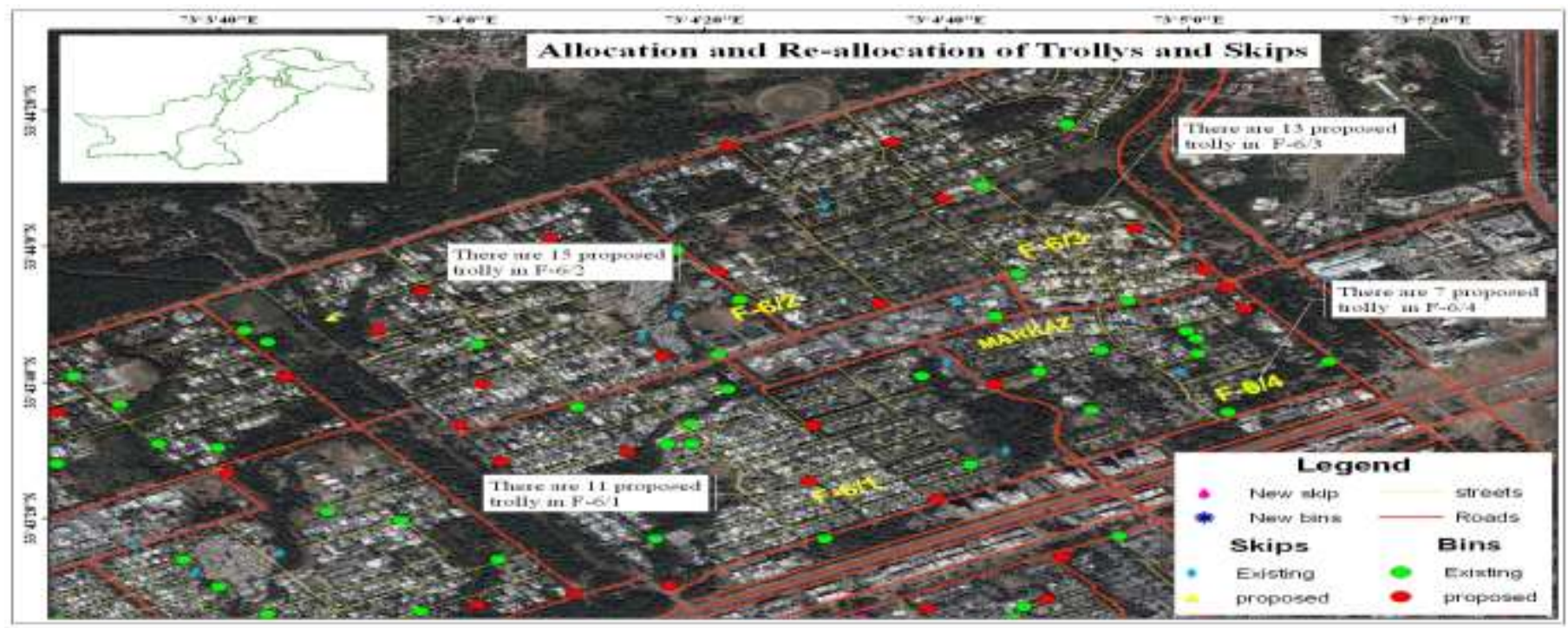

Fig. 7: Reallocation of existing and Allocation of new trolley and skips in Sector F-6

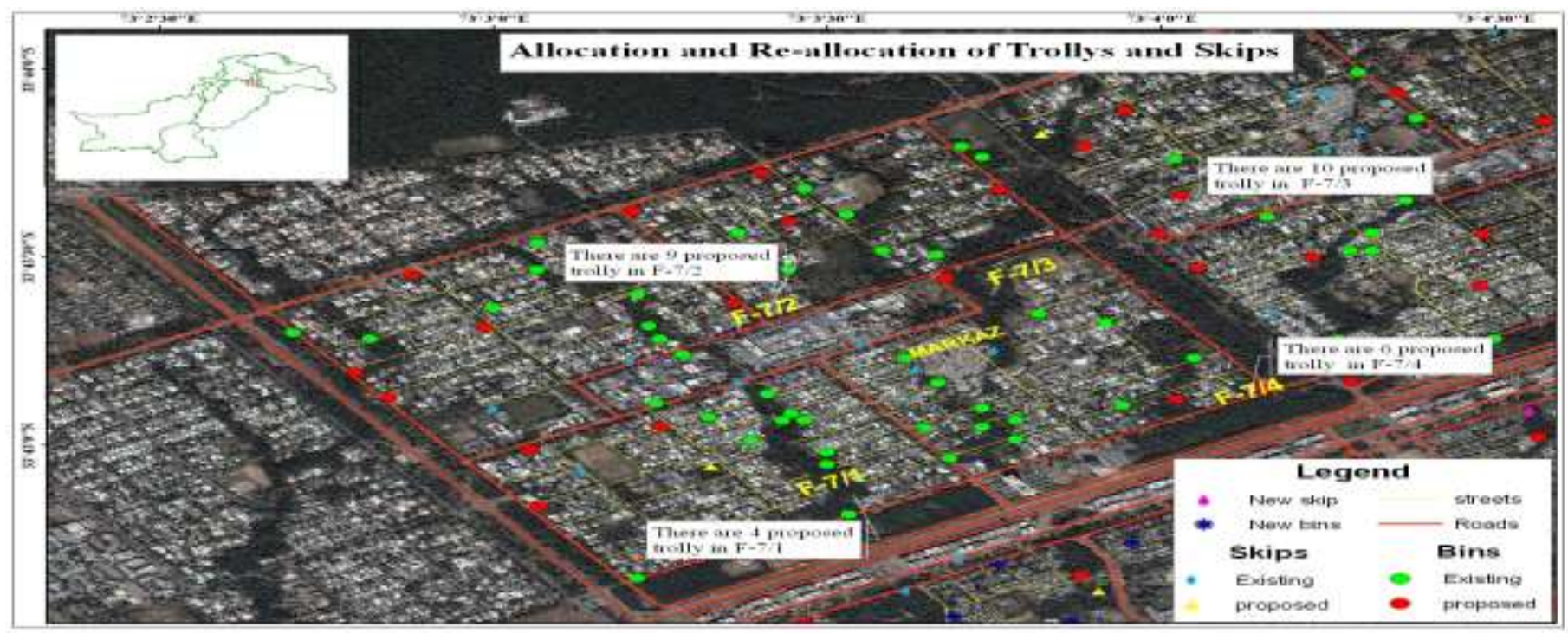

Fig. 8: Reallocation of existing and Allocation of new trolley and skips in Sector F-7

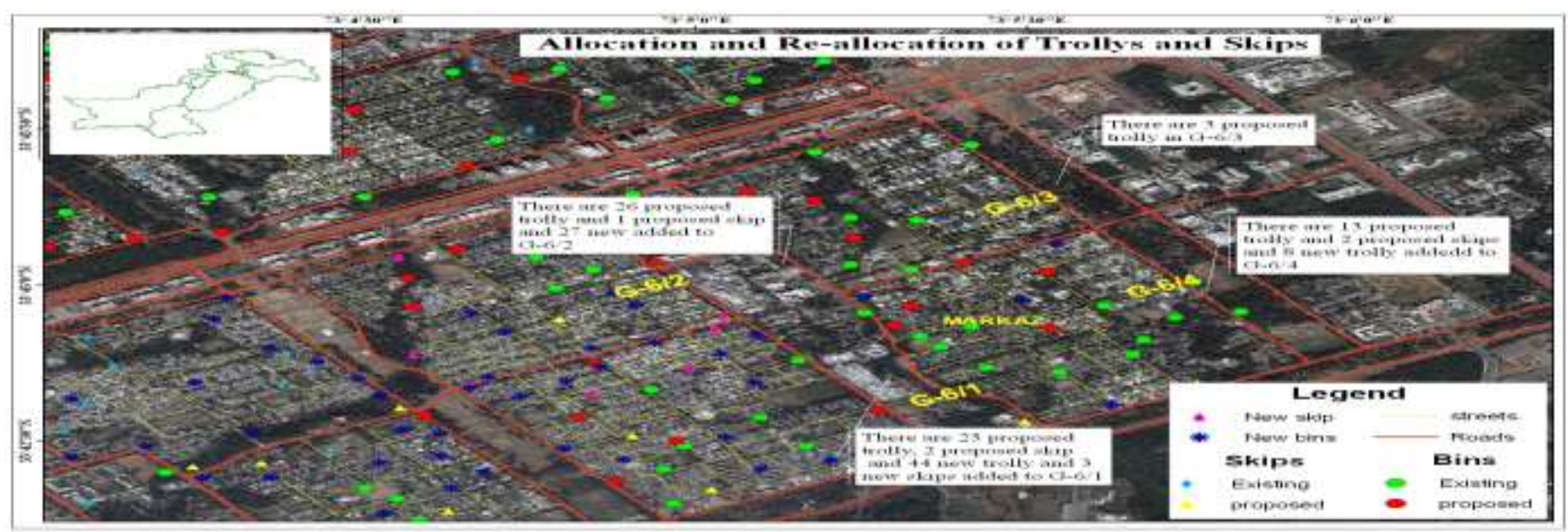

Fig. 9: Reallocation of existing d Allocation of new trolley and skips in Sector G-6 


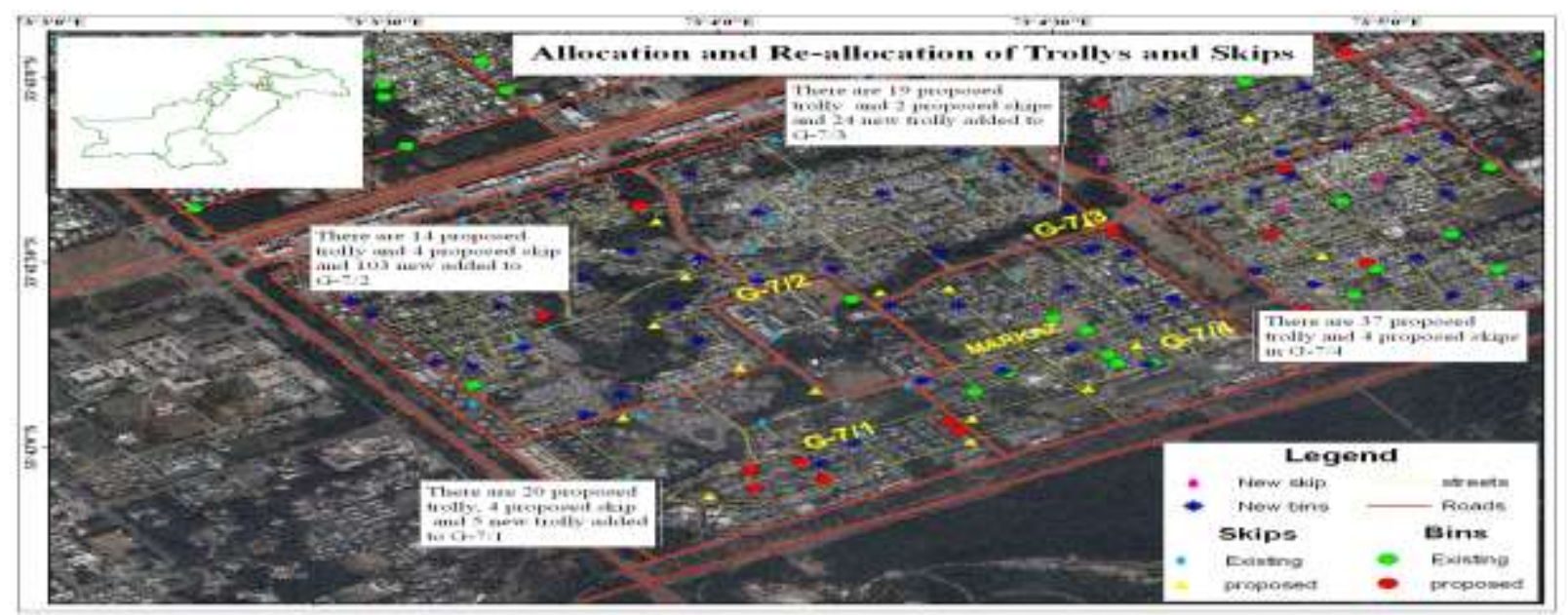

Fig. 10: Reallocation of existing and Allocation of new trolley and skips in Sector F-7

In all there were 19 out of 38 skips in the sector. There were 90 trolleys and 14 skips which were suggested to be placed in the proposed area. In all there are 132 new trolleys need to be placed in the sector having high waste generation rate.

\section{Conclusion}

The study reveals that the waste generation is high than the carry capacity of waste bins in the study area. The numbers of waste bins are not properly distributed according to the waste generation pattern. The large numbers of waste bins are placed in less populated sector i.e F-6 and F-7. On the contrary, less number of waste bins is place in highly populated sector i.e G-6 and G-7.There is no proper allocation of waste bins in the study area. Waste bins were found in close proximity of sensitive area like school, hospitals etc. There is also an imbalance in the distributions of bins in the area. There were some places where the large number of bins was placed and some places were left empty.

\section{Acknowledgment}

We acknowledge the cooperation from the Pakistan Science Foundation(PSF) in providing financial support".

\section{References}

[1] AmponsahS.K ,Salhi S., 2004. The investigation of a class of capacitated arc routing problems: the collection of garbage in developing countries. Waste Management $24,711-721$.

http://dx.doi.org/10.1016/j.wasman.2004.01.008

[2] Chattopadhyay, S. Dutta, A. Ray, "Municipal solid waste management in Kolkata", Waste Management ,Vol.2 , pp.1449-1458,2008.

[3] D.C .Meshram, G.M. Pondhe, S.N.Thitame, 2009. Characterisation and composition of Municipal Solid Waste (MSW) generated in Sangamner City, District Ahmednagar, Maharashtra, India. Environmental Monitering and Assessment , pp.1-5.

[4] F.R. McDougall, P.R White, M.Franke, P. Hindle, "Integrated Solid Waste Management:" A Lifecycle Inventory, Blackwell Science, London. 2001

http://dx.doi.org/10.1002/9780470999677

[5] G.E. Blight, C.M Mbande, 1996. Some Problems of Waste Management in Developing Countries. pp. 19-27.

[6] Meshram, D.C., Pondhe, G.M., Thitame,S.N., 2009. Characterisation and composition of Municipal Solid Waste (MSW) generated in Sangamner City, District Ahmednagar, Maharashtra, India. Environmental Monitering and Assessment 170, 1-5.

[7] Narayana T, Municipal solid waste management in India: From waste disposal to recovery of resources, Waste Management, vol.29, pp.1163-1166, 2008. 
http://dx.doi.org/10.1016/j.wasman.2008.06.038

[8] Pak-EPA, Guidelines for Solid Waste Management, Pak-EPA in collaboration with JICA, Ministry of Environment, PEP and UNDP, 2005.S.K. Amponsa, S. Salhi,“ The investigation of a class of capacitated arc routing problems: the collection of garbage in developing countries,” Waste Management vol.24. pp. 711-721, 2004. 